\title{
Immune complexes in retinitis pigmentosa
}

\author{
C. D. HEREDIA, ' J. HUGUET, ${ }^{2} \mathrm{~N}$. COLS, ${ }^{2}$ P. ENGEL,$\stackrel{2}{ }$ AND \\ P. A. GARCÍA-CALDERÓN?
}

From the 'Barraquer Ophthalmology Centre, Barcelona; and 'Immunolab, Barcelona, Spain

SUMMARY In a group of 46 patients with retinitis pigmentosa (RP) we studied the presence of circulating immune complexes (CIC) and the alterations in the complement system. Our results showed the presence of CIC in $43.5 \%$ of the patients studied, reduced levels of the complement components $\mathrm{C} 3$ and $\mathrm{C} 4(\mathrm{p}<0 \cdot 001)$, and of the haemolytic activity $\mathrm{CH} 50(\mathrm{p}<0 \cdot 001)$ when compared with a control group consisting of a 100 healthy subjects. We found a statistically significant correlation between the values of $\mathrm{C} 3$ and $\mathrm{CIC}(\mathrm{p}<0 \cdot 01), \mathrm{C} 4$ and $\mathrm{CIC}(\mathrm{p}<0 \cdot 01)$, and between $\mathrm{CH} 50$ and CIC $(\mathrm{p}<0 \cdot 001)$. These findings indicate that the CIC may play a role in the pathogenesis of primary retinitis pigmentosa.

There have been few studies to date on the possible presence of immunochemical alterations in retinitis pigmentosa (RP). In 1966 Fessel' described for the first time the presence of a rheumatoid factor and raised IgM in six out of 10 cases of RP. In $1973 \mathrm{Rahi}^{2}$ found raised levels of IgM in patients with RP, whereas Spalton et al. ${ }^{3}$ detected raised levels of this immunoglobulin in only five out of 17 subjects with RP and rheumatoid factor in only two out of 17 patients. The levels were normal for the remaining immunoglobulins tested as well as for the $\mathrm{C} 3$.

The existence of an immune response to the antigens of the pigment epithelium and to the rod outer segments ${ }^{\dagger}$ could provoke an inflammatory reaction with retinal oedema in patients with degenerative processes of the retina determined genetically, ${ }^{3}$ where an increase in the vascular permeability in subjects with diverse genetic types of RP takes place. ${ }^{5}$

The increase in permeability and oedema in RP have led some authors ${ }^{3}$ to believe in the possible existence of circulating immune complexes (CIC). These authors have suggested the possible formation and deposit of these at a local level. The deposit of $\mathrm{CIC}$ in situ would produce an inflammation where the CIC would play a major role in provoking tissue injury." On the other hand there is some evidence that CIC play an important part in the pathogenesis of a wide variety of inflammatory autoimmune disorders, ${ }^{7}$ even having been detected in apparently healthy subjects. ${ }^{ }$

Correspondence to Dr P. A. García-Calderón, Immunolab, Pau Claris 162. Barcclona 37. Spain.
Although CIC in humans do not necessarily involve a pathogenic action they frequently reflect an alteration in the immune system. The adherence of CIC to mononuclear $\mathrm{T}$ and/or B cells influences the crucial cell to cell interaction which is necessary for the immune response" and which has been found to be altered in subjects with RP. "' "I

All these considerations prompted us to carry out this study of the possible presence of CIC in 46 patients with RP in whom we also determined the C3 and $\mathrm{C} 4$ levels as well as the haemolytic units of complement $(\mathrm{CH} 50)$.

\section{Material and methods}

Patients. We studied a group of 46 patients with RP, 29 males $(63 \%)$ and 17 females $(37 \%)$, aged between six and 51 years (average age 26 years). For the diagnosis of RP the following symptoms and signs were taken into account: loss of field of vision, arteriolar narrowing, pigment accumulation, poor adaptation to light and/or darkness, and abolished electroretinogram.

Controls. The control group consisted of 100 healthy subjects: 58 males $(58 \%)$ and 42 females $(42 \%)$ aged between 16 and 48 years (average age 25 years). The controls were free from ocular alterations and immunological abnormalities of whatever origin. They were subjected to the same immunological studies as the patient group with the exception that the determination of the possible presence of CIC and the values of these were carried out in only 70 of the 100 subjects. 
Study of the levels in $\mathrm{mg} / \mathrm{dl}$ of the complement components $C 3$ and $C 4$. These were determined with an ICS Beckman nephelometer using antisera from Kallestad (Austin, Texas, USA). The main characteristics of this technique are described in Buffone.'?

Determination of the number of the haemolytic units of complement (CH5O). This modified version of Lachmann's technique, fully described in Weir ${ }^{1.3}$ is based on the time that is necessary to obtain a $50 \%$ lysis using a known quantity of complement. Briefly, $15 \mu \mathrm{l}$ of serum of the patient or control is mixed with $750 \mu \mathrm{l}$ of complement fixing diluent (CFD) prewarmed to $37^{\circ} \mathrm{C}$, with the addition of $250 \mu \mathrm{l}$ of $0.2 \%$ sheep red blood cells (EA). The mixture is aspirated into the cuvette of a spectrophotometer (Beckman $34 \mathrm{C}$ ), which records a curve of haemolysis until $100 \%$ lysis is reached, followed at $600 \mathrm{~nm}$ of optical density (OD). A curve is then plotted with the use of normal human serum (NHS) as measured by the Mayer technique. We represented the units of $\mathrm{CH} 50$ in the abscissae and the time to obtain $50 \%$ haemolysis in the ordinates. After calculating the time of $50 \%$ haemolysis of a problem serum we can extrapolate the $\mathrm{CH5}$ ) units of this serum.

Study of the presence of $\mathrm{CIC}$. The technique described by Harkiss and Brown ${ }^{14}$ was used. $0.3 \mathrm{ml}$ serum from patients or controls was added to $50 \mu \mathrm{l}$ of borate buffer and to $50 \mu \mathrm{l}$ of EDTA of $0.2 \mathrm{M}$. The solutions were mixed in PS-3 tubes (Aulabor, Barcelona, Spain). To these tubes $0.1 \mathrm{ml}$ of a polyethylene glycol (PEG) solution of $12.5 \%$ was added before mixing and was left for $90 \mathrm{mins}$ at $4^{\circ} \mathrm{C}$. After centrifugation at $1700 \mathrm{~g}$ for $10 \mathrm{~min}$ the supernatants were removed, and the pellets were washed with $1 \mathrm{ml}$ of $2.5 \%$ PEG solution. After further centrifugation the pellets were resuspended in $30 \mu$ of warm CFD to which were added $15 \mu \mathrm{l}$ of NHS (fresh or frozen at $-70^{\circ} \mathrm{C}$ ). At this stage two control tubes were introduced, $30 \mu \mathrm{l} \mathrm{CFD}$ at $37^{\circ} \mathrm{C}$ plus $15 \mu \mathrm{l}$ of NHS. These were incubated for $30 \mathrm{~min}$ at $37^{\circ} \mathrm{C}$ and then deposited in an ice bath. The tubes were made up to

Table 1 Means values and deviations of $\mathrm{C} 3, \mathrm{C} 4, \mathrm{CH}$ (), and $(I C$ of controls $(C)$ and patients $(P)$ with $R P$

\begin{tabular}{|c|c|c|c|}
\hline & C & $P$ & \\
\hline & $n=I 00$ & $n=46$ & \\
\hline \multirow[t]{2}{*}{$\mathrm{C} 3 \mathrm{in} \mathrm{mg} / \mathrm{dl}$} & $\bar{x}=129 \cdot 80$ & $\bar{x}=106.67$ & $p<() \cdot(x) 1$ \\
\hline & $S D=23.51$ & $S D=21 \cdot 6.3$ & \\
\hline \multirow[t]{2}{*}{ ('4 in $\mathrm{mg} / \mathrm{dl}$} & $\bar{x}=29.93$ & $\overline{\mathrm{x}}=22 \cdot(19)$ & $\mathrm{p}<() \cdot(x) 1$ \\
\hline & $S D=8.65$ & $S D=8 \cdot 18$ & \\
\hline \multirow{2}{*}{$\begin{array}{l}\text { CH50 hacmolytic } \\
\text { units } / \mathrm{ml}\end{array}$} & $\bar{x}=37 \cdot 1.3$ & $\bar{x}=29 \cdot 61$ & $\mathrm{p}<0(1) \cdot(x) 1$ \\
\hline & $\begin{array}{l}\mathrm{SD}=7 \cdot 38 \\
n=70\end{array}$ & $S D=7.61$ & \\
\hline \multirow[t]{2}{*}{$\mathrm{CIC}$ in $\% \mathrm{CC}$} & $\bar{x}=8 \cdot 10$ & $\bar{x}=20.35$ & $p<() \cdot(x) 1$ \\
\hline & $\mathrm{SD}=5 \cdot 78$ & $\mathrm{SD}=14 \cdot 5.5$ & \\
\hline
\end{tabular}

Sl conversion: $\mathrm{mg} / \mathrm{dl} \times \mathrm{l}(0=\mathrm{mg} / \mathrm{l}$.
$0.75 \mathrm{ml}$ with CFD. Afterwards $0.25 \mathrm{ml}$ of a suspension of $0.2 \%$ EA (at $37^{\circ} \mathrm{C}$ ) was added to each sample, and the decrease in turbidity due to lysis of the red cells was followed at $600 \mathrm{~nm}$ OD using a Beckman 34C spectrophotometer with an automatic sample changer with cuvettes at $37^{\circ} \mathrm{C}$ to be monitored continuously. The CH50 units were determined for each sample and control The results were initially expressed as residual $\mathrm{CH} 50$ units and subsequently as percentages of complement consumption (CC) with respect to $0 \%$ of the consumption of the control tubes.

$$
\% \mathrm{CC}=100 \times\left(1-\frac{\text { Units }(\mathrm{H} 50) \text { test solution }}{\text { Units CH5) control }}\right) .
$$

\section{Results}

Table 1 shows the mean values and deviations in $\mathrm{mg} / \mathrm{dl}$ of the complement components (SI conversion: $\mathrm{mg} / \mathrm{dl} \times 10=\mathrm{mg} / \mathrm{l})$. The $\mathrm{C} 3$ levels for the controls were $129 \cdot 80 \pm 23 \cdot 51 \mathrm{mg} / \mathrm{dl}$ and for the group of 46 patients with RP $106.67 \pm 21.63 \mathrm{mg} / \mathrm{dl}$, showing a statistically significant difference $(\mathrm{p}<0 \cdot(0) 1)$. The $\mathrm{C} 4$ levels were $29.93 \pm 8.65 \mathrm{mg} / \mathrm{dl}$ for the control group and $22.09 \pm$ $8.18 \mathrm{mg} / \mathrm{dl}$ for the patient group $(\mathrm{p}<0 \cdot 001)$. For the control group the $\mathrm{CH} 50$ units were $37 \cdot 13 \pm 7 \cdot 38$, whereas the patient group registered 29.61 $27 \cdot 61$ $(p<0 \cdot 001)$. The study of the presence of CIC gave a mean and standard deviation of $8 \cdot 10 \pm 5.78$ for the control group and 20.35 $\pm 14.55(\mathrm{p}<0.001)$ for the patient group. If we consider the presence of CIC positive, where the percentage of $\mathrm{CC}$ is greater than the mean plus two standard deviations of the control group, we end up with $43.5 \%$ of patients with levels of CC greater than $20 \%$ (Fig. 1).

If the $\mathrm{C} 3$ values in $\mathrm{mg} / \mathrm{dl}$ are compared with the CIC values (in CC\%) in the patient group, a signficant correlation may be observed between the diminution in $\mathrm{C} 3$ and the increase in $\mathrm{CIC}(\mathrm{r}=-0.4185, \mathrm{p}<0 \cdot() 1$, Fig. 2). Likewise, a significant correlation exists between the diminution in $\mathrm{C} 4$ and the increase in CIC $(r=-0.407, p<0 \cdot 01$, Fig. 3) and between the diminution in $\mathrm{CH} 50$ units and the increase in percentage of complement consumption $(r=-0.536$, $\mathrm{p}<0 \cdot 0(01$, Fig. 4).

\section{Discussion}

It is generally accepted that the presence of CIC has a limited diagnostic value, and that this does not always characterise all immune complex disease. ${ }^{15}$ In order to speak of an immune complex disorder it is necessary to be able to associate the clinical activity of the disease with variations in the level of CIC, haemolytic activity of the complement, functional activity of the complement components, or the presence of raised values of the degradation products of the complement. ${ }^{7}$ 


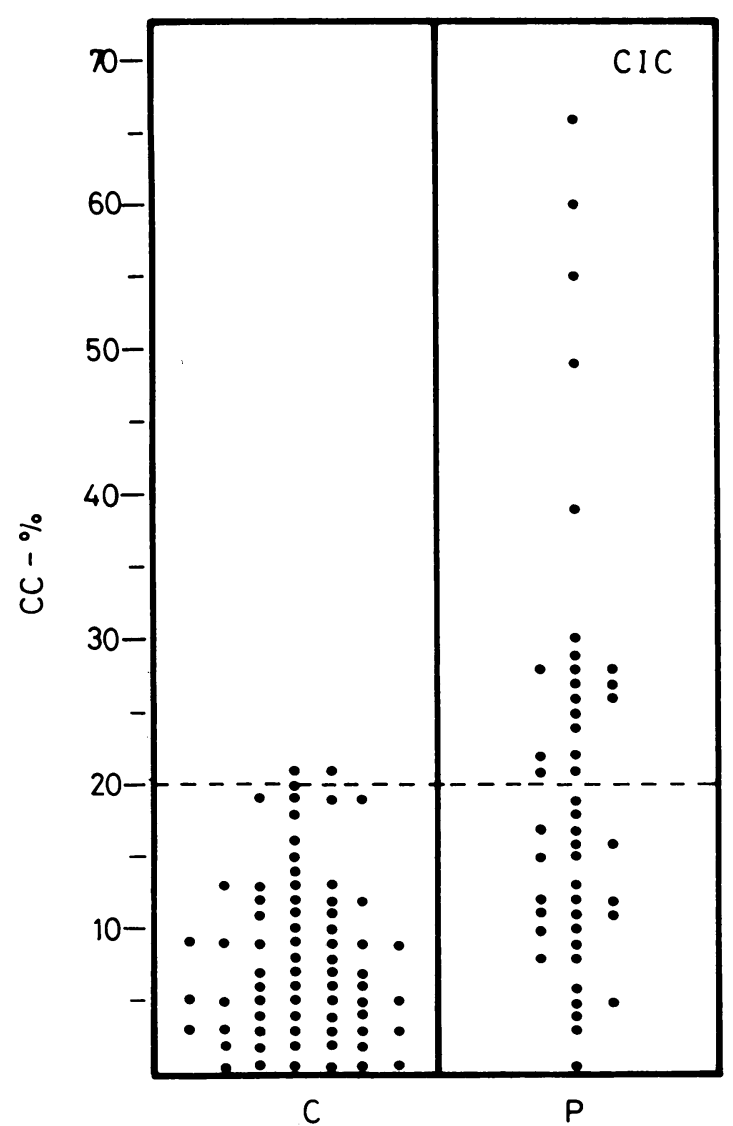

Fig. 1 Levels of immune complexes (complement consumption in percentages) of controls $C$ and patients $P$ with $R P$.

Since the CIC contain Clq, C1r, Cls, C3, and immunoglobulins it is difficult to demonstrate the presence and identify the antigen, and therefore we have to consider the possibility that at times the CIC

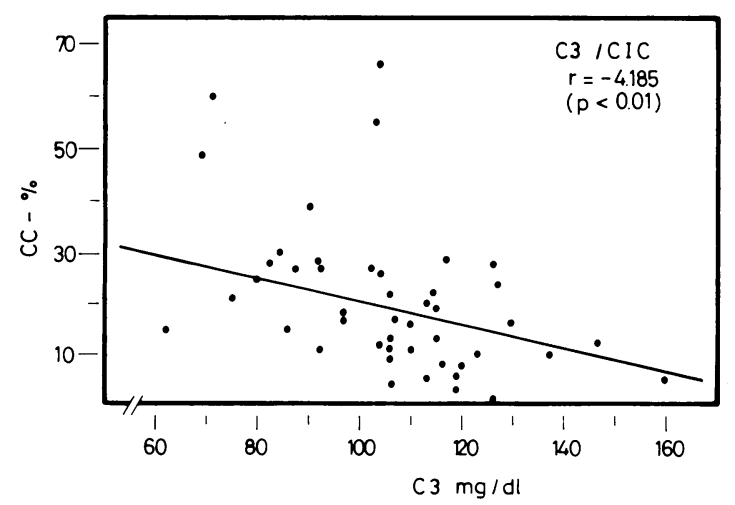

Fig. 2 Correlation between the values of $\mathrm{C} 3$ and $\mathrm{CIC}$ in the patient group.

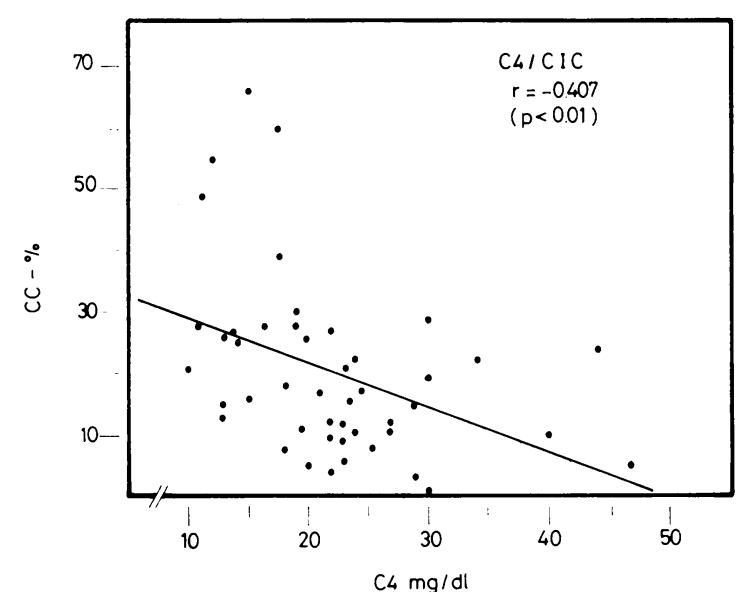

Fig. 3 Correlation between the value's of $\mathrm{C} 4$ and CIC in the patient group.

may result from the interaction of immunoglobulin molecules without antigen participation. " Autoantibodies are directed against antigenic sites located in the immunoglobulin constant region. ${ }^{17}$ Other autoantibodies are directed against the idiotypic determinants of the immunoglobulins ${ }^{1 \mathrm{x}}$ (antigenic sites located in the hypervariable region of the immunoglobulins). The existence of these does not always give rise to a pathogenic action, since it is generally accepted that the repertoire of a person's antibodies comprises a network of idiotype and anti-idiotype antibodies in which the immunoglobulins function both as antibodies for some immunoglobulins and as antigens for other immunoglobulins. ${ }^{19}$ Therefore the antibodies (independent or as CIC) play a part in the immune homoeostasis, where the CIC may have opposing roles, both enhancing and inhibiting the immune response. ${ }^{21}$

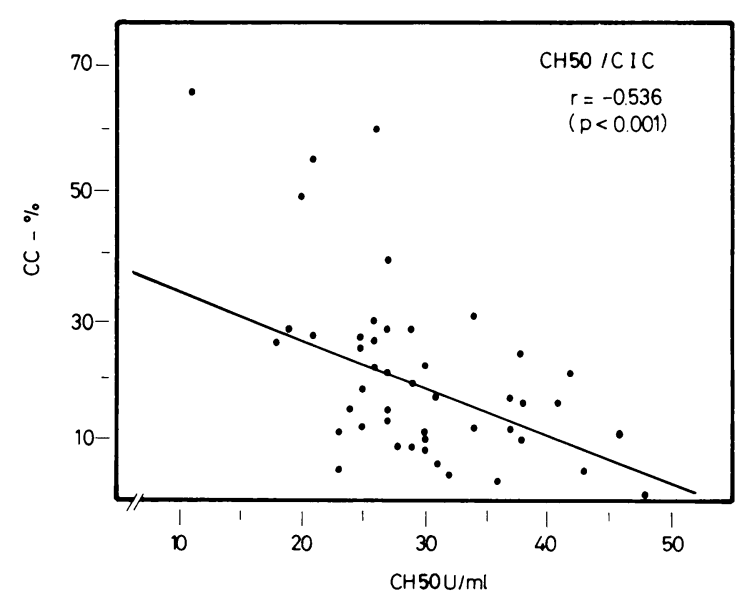

Fig. 4 Correlation between the values of $\mathrm{CH}$. the patient group. 
From our results we can infer the existence of CIC in $43.48 \%$ of the patients with RP under study, and this may have a certain pathogenic significance in this disorder owing to the existence of a correlation (see 'Results') between the levels of these and the fall in the $\mathrm{C} 3$ and $\mathrm{C} 4$ complement components and $\mathrm{CH} 50$ haemolytic activity. Thus, these CIC activators of the complement could produce the release of anaphylotoxins ( $\mathrm{C} 3 \mathrm{a}$ and $\mathrm{C} 5 \mathrm{a}$ ) of the $\mathrm{C} 3$ and $\mathrm{C} 5$ complement components, leading to the release of histamine by mast cells and basophils, with the subsequent increase in the vascular permeability ${ }^{21}$ in the ocular structures, ${ }^{5}$ in which small particles of deaggregated CIC could diffuse on solubilisation after union with $\mathrm{C} 3.2$

In conclusion, the affirmation of the presence of CIC in RP may have a certain prognostic value in the evolution of this process if, as in other diseases, it can be proved that the presence of CIC at the time of diagnosis leads to fewer remissions and a poorer prognosis than in those cases where they are not detected. ${ }^{2.3}$

\section{References}

1 Fessel WJ. Scrum protein disturbance in retinitis pigmentosa. Am J Ophthalmol 1962; 53: 640-2.

2 Rahi AHS. Autoimmunity and the retina. II. Raised serum IgM levels in retinitis pigmentosa. Br J Ophthalmol 1973; 57: 904-9.

3 Spalton DJ, Rahi AHS, Bird AC. Immunological studics in retinitis pigmentosa. BrJ Ophthalmol 1978; 62: 183-7.

4 Brinkman CJJ, Pinckers AJLG, Broekhuyse RM. Immune reactivity to different retinal antigens in patient suffering from retinitis pigmentosa. Invest Ophthalmol Visual Sci 1980; 19: 743-50.

5 Spalton DJ, Bird AC, Cleary PE. Retinitis pigmentosa and retinal oedema. BrJ Ophthalmol 1978; 62: 174-82.

6 Marker SP, Moorthy B. In situ immune complex formation in isolated perfused kidncy using homologous antibody. Lab Invest 1981; 44: 1-5.

7 Nydegger VE, Kazatchkine MD, Lambert PH. Immune complexes. In: Fougereau M, Dausset J, eds. Progress in immunology IV. London: Academic Press, 1980: 4: 1026-43.
8 Theofilopoulus AN, Andrews BJ, Urist MM, Morton DL, Dixon FJ. The nature of immune complexes in human cancer sera. $J$ Iminunol 1977; 119: 657-63.

9 Griffin FM. Effects of soluble immune complexes on Fe receptor and $\mathrm{C} 3 \mathrm{~b}$ receptor mediated phagocytosis by macrophages. J Exp Med 1980); 152: 905-19.

10 Rocha H. Antunes C. Primary retinitis pigmentosa-autoimmunity? Metab Ophthalmol 1977; 1: 153-6.

11 Heredia CD, Vich JM. Huguet J, García-Calderón JV, GarcíaCalderón PA. Altered cellular immunity and suppressor cell activity in patients with primary retinitis pigmentosa. $\mathrm{BrJ} \mathrm{Oph}$ thalmol 1981; 65: 850-4.

12 Buffone GJ. Immunonephelometric and turbimetric measurement of specific plasma protein. Manual of clinical immunology. Washington: Amcrican Society for Microbiology. 1980: 23-8.

13 Weir DM. Handbook of experimental immunology. Oxford: Blackwell, 1979: 5A-12.

14 Harkiss GD, Brown DL. Detection of immunecomplexes by a new assay, the polyethylene glycol precipitation-complement consumption test (PEG-CC). Clin Exp Immunol 1979; 36: $117-29$

15 Visher TL, Veys E. Symoens J. Rosenthal M. Huskisson EC. Levamisole in rhcumatoid arthritis. A randomized double-blind study comparing two dosage regimens of levamisole with placebo. 1978: Lancet ii: $1(007-12$.

16 Casali P. Lambert PH. Purification of soluble immune complexes from serum using PMMA beads coated with conglutinin or Clq. Clin Exp limmunol 1979; 37: 295-309.

17 Lambert PH, Berncy M. Kazymba L. Immune complexes in serum and cerebrospinal fluid in African trypanosomiasis. J Clin Invest 1981; 67: 77-85.

18 Cosenza A. Detection of anti-idiotype reactive cells in the response to phosphorylchrolinc. Eur J Immunol 1976; 6: 114-8.

19 Jerne NK. Towards a network theory of the immune system. Ann Immunol (Paris) 1974; 1250: 373-89.

20) Theofilopoulos AN. Dixon FJ. The biology and detection of immune complexes. In: Dixon FJ, Kunkel HG, eds. Advances in immunology. New York: Academic Press, 1979: 89-220.

21 Rossen RD. Immune complexes, anti-immunoglobulins, and discase. In: Twomey JJ, ed. The pathophysiology of human immunologic disorders. Baltimore-Munich: Urban and Shwarzenberg, 1982: 149-72.

22 Miller GW, Nussenzweig V. A new complement function: solubilization of antigen-antibody aggregates. Proc Natl Acad Sci USA 1975; 72: 418-22.

23 Carpentier N, Lange G, Ficre D, Fournic G, Lambert PH, Micscher PA. Clinical relevance of circulating immune complexes in human leukemia: association in acute leukemia of the presence of immune complexes with unfavorable prognosis. J Clin Invest 1977: 60: 874-84. 